\title{
Can Confucius excuse poor creativity?
}

Respect for authority is not conducive to the sceptical thinking that accompanies originality. But Korea's strong Confucian values are less of an impediment to the country's scientific progress than other, more commonplace obstacles.

KorEA, so Koreans say, is one of the few Asian countries in which students bow to their professors. That, those professors will tell you, is a symptom of Confucian traditions of respect for elders and for scholarship. Probably as a by-product of the country's historical need to preserve its national and cultural identity in the looming presence of China and Japan, the Confucian tradition remains stronger in the Republic of Korea than in any other country.

That tradition is one of the cultural strengths that has helped the nation make extraordinary strides in industrial power in recent decades. As with other Asian states, autocracy from the top and respect from below, combined with sheer unflagging hard work, has allowed Korea to extract its sizeable share of wealth from the global economy. And this at a time when the nation has been on a perpetual war footing against bellicose cousins to the north.

Now Korea needs that purpose and resilience as much as ever. Other states are supplying cheaper labour - Korean wages have doubled over the last few years - while export revenue in at least one of its key industrial sectors, semiconductor circuits, appears wobbly. The country has met the challenge of moving to higher added-value products only to a limited extent. The country's industrial giants are widely perceived as overly protected and slow to take on new challenges. That is probably too much of a generalization. Nevertheless, although industry spends much money on $\mathrm{R} \& \mathrm{D}$, senior figures speak of a need for more in the way of fundamental technological innovation.

What of science amidst all of this? To its enormous credit, the country has established an academic science base virtually from scratch over the last two to three decades. Although there are over 100 national and private universities, only fifteen or so could be said to constitute part of the science research base, and only a handful of those are now perceived to be foreseeably capable of establishing themselves firmly in the international league. The influence of the United States in this extraordinarily rapid development cannot be overstated. It is no coincidence that the university that achieved the highest ranking in science and technology in a recent survey, the Pohang University of Science and Technology, was set up - as recently as nine years ago - with a mass import of Koreans from excellent US institutions.

Of course it takes researchers in any country several years to build up a world-class laboratory. But Koreans, ever self critical, rightly fret about other factors that limit their scientific achievements, and their apparent lack of creativity in particular. Take schools, for instance. Parents spend as much as $50 \%$ of their income on high school education in order to get their young into prestigious universities, on which subsequent careers depend too heavily. That process leaves young university students crammed to the brim with knowledge but with little experience of imaginative and creative thinking. Those that do not, exhausted, put their feet up, but instead wish to take science seriously, find themselves in a university system in which a Confucian respect for authority and the need to get through the next exams are paramount.
All that, say young and not-so-young Korean academics, seriously undermines their capacity for creativity. And those who have returned from the creative hot-houses in the West? As soon as they return, it is said with a rueful laugh, they become Koreans again.

Maybe there is hope to be had in the fact that Confucian standards are slipping. Not often nowadays will young researchers wait for their laboratory heads to go home before they themselves pack up for the day. But to place much emphasis on such change would be misguided. The prime needs of Korean researchers are those that their Western counterparts would find all too familiar - less bureaucracy and less short-termism and, in some disciplines, better supplies of equipment and more ready access to consumables from abroad.

\section{Distractions}

The burdens of bureaucracy arise most obviously in the funding of research. Grants are awarded for periods of up to three years (and in a new scheme some will be awarded for up to five) but young scientists find themselves obliged to produce reports and even, some say, publications every year. That is too onerous a burden on people engaged in the medium-term development of centres of high-quality research. The various ministries that support university research should take steps to diminish their administrative zeal. Senior academics should ensure that their younger staff are not mopping up too much of the paperwork. At the same time, staff-student ratios should be increased to reduce teaching burdens.

Short termism stems from the top. Korea's Economic Planning Board is responsible for overall policy, and is widely seen to be dominated by economists and industrialists with blinkered views as to the purposes of research. That perspective infects too many of the country's sources of research funding. True, a greater emphasis on basic research is apparent in recent policy developments, but much more will be needed in order to fulfil at least one of the next aims of the Korean government: to develop a strong scientific base in the life sciences that will stimulate associated industries.

Despite the problems, this is no bad time to be a Korean scientist. Research budgets from all sources are set to increase faster than inflation, science is receiving priority attention from the government, and science and technology - and the skills that go with them - are widely perceived to be essential for Korea's next phase of development. Increased competitiveness and mobility in appointments, and making foreign researchers more welcome with practical support, would help the country move even faster to the excellence it seeks.

So how to boost scientific creativity? Confucian values notwithstanding, receptivity and support for new ideas is what counts. Korea already has its centres of excellence. Now it needs to give its brightest researchers ample time to think, to be stimulated by contact with researchers at the leading edge overseas, and - gradually - to bloom. What better defining quality for the next decade of the country's scientific history? And what better seeds of technological and economic innovation in the decades to follow? 